\title{
Vessel Speed Analysis before and after Dredging near Missouri River Mile 282 in \\ November 2020
}

US Army Corps of Engineers ${ }_{\circledast}$ by Marin M. Kress

PURPOSE: The purpose of this Coastal and Hydraulics Engineering Technical Note (CHETN) is to present information on vessel traffic before, during, and after a dredging event around river mile 282 of the Missouri River in November 2020 along with contextual information about tonnage and commodities that utilize this navigation project.

INTRODUCTION: The Missouri River-Kansas City to the Mouth navigation project stretches approximately 374 miles from Kansas City, MO, to the mouth of the Missouri River where it flows into the Mississippi River (Figure 1). This section of waterway handled a total of 3,974,064 tons of cargo in 2019, the most recent year for which data are available. Of that tonnage, almost 3.5M tons was Sand and Gravel, with the next highest commodity tonnage category being Asphalt, Tar, and Pitch (USACE-WCSC 2021). The entire amount of sand and gravel is recorded as being "Intrawaterway" tonnage, which means that the traffic stays "within the limits of a river, waterway, or canal" (USACE 1996). In this case, the intrawaterway traffic stays within the Missouri River. Table 1 displays the top commodity groups and their associated tonnage totals that moved on Missouri River-Kansas City to the Mouth project during 2015-2019.

Table 1. Commodity tonnage calendar year (CY) 2015-2019, Missouri River-Kansas City to the Mouth project.

\begin{tabular}{|c|c|c|c|c|c|}
\hline Commodity & CY2015 & CY2016 & CY2017 & CY2018 & CY2019 \\
\hline Total: All Commodities & $4,175,945$ & $4,403,752$ & $4,758,503$ & $4,380,631$ & $3,974,064$ \\
\hline Sand and Gravel & $3,674,860$ & $3,597,013$ & $3,806,420$ & $3,514,319$ & $3,452,917$ \\
\hline Asphalt, Tar, and Pitch & - & 32,186 & 42,051 & 104,301 & 114,503 \\
\hline $\begin{array}{l}\text { Waterway Improvement } \\
\text { Material }\end{array}$ & 231,905 & 247,719 & 215,896 & 109,782 & 93,225 \\
\hline Fertilizer and Mixes NEC* & 29,478 & 49,557 & 43,953 & 66,621 & 72,330 \\
\hline Cement and Concrete & 82,920 & 97,815 & 98,490 & 256,641 & 64,140 \\
\hline Soybeans & 12,864 & 133,124 & 139,919 & 101,014 & 55,703 \\
\hline Nitrogenous Fertilizer & 25,145 & 52,095 & 31,332 & 34,451 & 39,217 \\
\hline Potassic Fertilizer & 17,828 & 38,380 & 36,058 & 25,418 & 17,383 \\
\hline Corn & 33,773 & 96,471 & 168,120 & 108,898 & 12,645 \\
\hline Slag & 3,092 & 2,972 & 9,265 & 9,563 & 12,372 \\
\hline $\begin{array}{l}\text { Miscellaneous Mineral } \\
\text { Products }\end{array}$ & & - & 84,000 & - & 8,900 \\
\hline $\begin{array}{l}\text { Clay and Refractory } \\
\text { Materials }\end{array}$ & 44,765 & 18,589 & 14,269 & 11,073 & 7,444 \\
\hline Iron and Steel Scrap & 2,928 & - & - & - & 7,427 \\
\hline Wheat & 3,269 & 1,745 & 3,174 & 6,203 & 6,707 \\
\hline Animal Feed, Prepared & - & - & 18,336 & 27,781 & 5,786 \\
\hline
\end{tabular}

*NEC $=$ Not Elsewhere Classified

Source: USACE-WCSC (Waterborne Commerce Statistics Center). 2021. Ports and Waterways Webtool. 2019 - Missouri River, Kansas City to the Mouth (WATERWAY) 5-Year Cargo Report. 
In 2020, shoaling was reported on the Lower Missouri River in the vicinity of river mile 282 along with channel restrictions (USACE-NWK 2020). Dredging activities to remove the shoal were arranged to maintain safe navigation through the area (Lowe 2020). Dredging operations occurred during November 11-14, very close to the end of navigation season. The navigation season on the Missouri River ends on December 1, 2020, limiting the amount of time available for post-dredging observations of vessel traffic. Anecdotal reports suggest that some vessel operators adjusted their activity in response to dredging plans, with some moving their operations either upriver or downriver, or choosing to avoid the area during dredging (Murray 2020). There is no clear evidence of a modal shift in cargo transportation due to shoaling on the Missouri River, and official tonnage statistics for 2020 were not available at the time of publication. However, there was interest in examining vessel movements in the area around river mile 282 before and after the dredge event as a preliminary attempt to quantify how dredging impacted local vessel traffic.

METHOD: For this preliminary analysis, the month of November 2020 was divided into predredging (November 1-10), during-dredging (November 11-14), and post-dredging (November 15-30) phases for a vessel traffic analysis. The initial study area spanned river mile 281 to 284 , shown below in Figure 1 with the associated National Channel Framework reach identification codes for those river reaches.

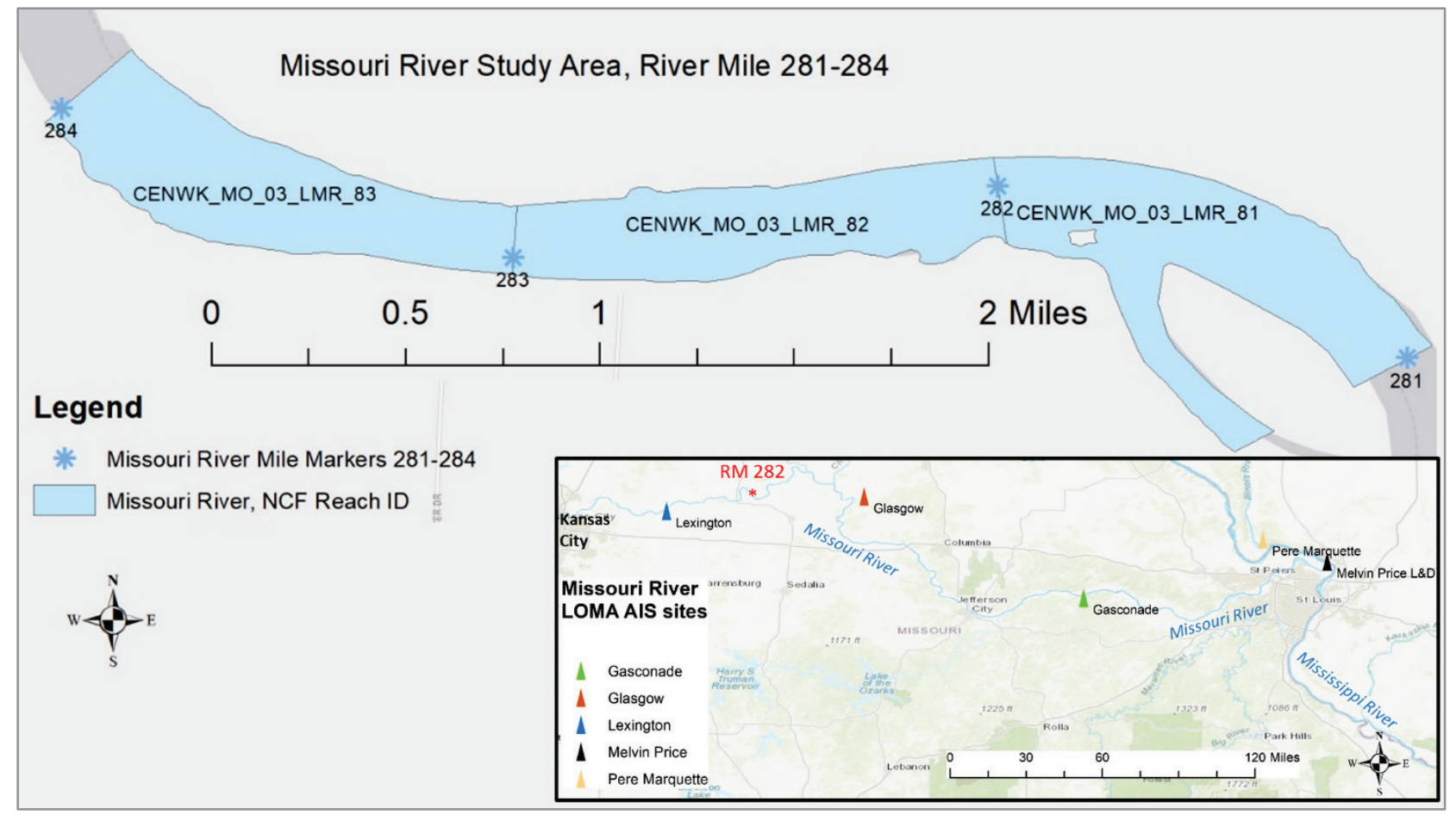

Figure 1. Missouri River study area river miles 281-284. Inset: Missouri River from Kansas City to the Mouth; AIS tower locations; river mile 282 marked with a red asterisk.

Automatic Identification System (AIS) records of historic vessel position reports were provided by the US Army Corps of Engineers (USACE), Lock Operations Management Application (LOMA) system, from the Glasgow, MO, site near river mile 230, for November 2020 (Figure 1). AIS records that fell within the study area were identified using the geospatial intersect tool in ArcMap 10.7.1 (ESRI 2019). These position reports are shown in Figure 2, below. Figure 2 shows a cluster of position reports around river mile 283; local reports indicated that this was related to rock placement for bank 
stabilization happening around the same time as dredging and not a traffic jam or course diversion resulting from the shoal itself.

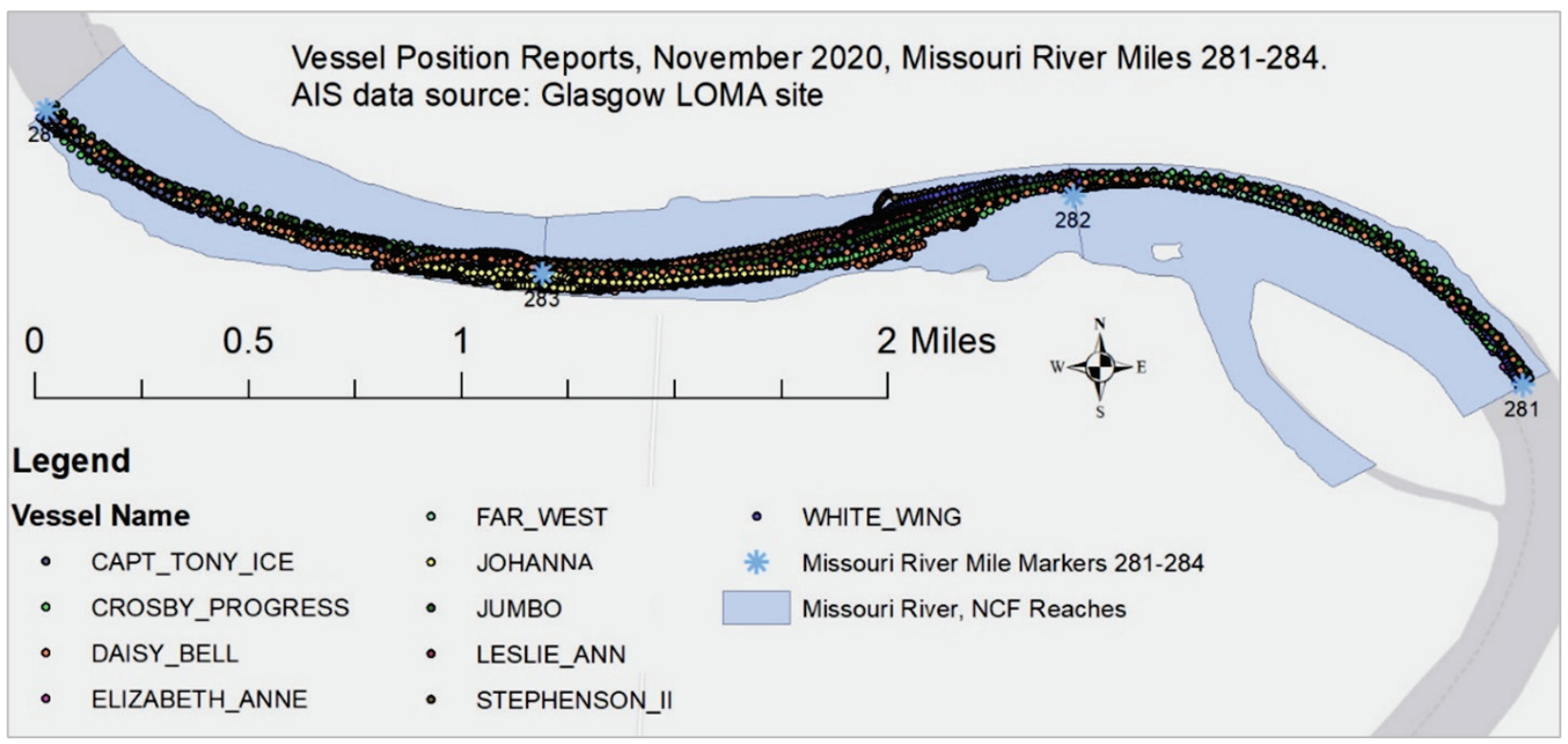

Figure 2. Vessel position reports, river miles 281-284, Missouri River, November 2020.

Only ten vessels were recorded via AIS data in this stretch of waterway during the month of November 2020. A list of the vessel names and Maritime Mobile Service Identity (MMSI) numbers are listed in Table 2, below.

\begin{tabular}{||l|c|c||}
\hline \multicolumn{3}{||c|}{ Table 2. Vessels observed within river miles 281-284, Missouri River, November 2020. } \\
\hline Vessel Name in AIS Message & Vessel MMSI Number & Vessel Type in AIS Message \\
\hline CAPT TONY ICE & 367057220 & Tug \\
\hline CROSBY PROGRESS & 367474790 & Dredger \\
\hline DAISY BELL & 367663940 & Other \\
\hline ELIZABETH ANNE & 367526190 & Tug \\
\hline FAR WEST & 368131420 & Tug \\
\hline JOHANNA & 367663280 & Tug \\
\hline JUMBO & 369970845 & Tug \\
\hline LESLIE ANN & 367718940 & Tug \\
\hline STEPHENSON II & 369970375 & Tug \\
\hline WHITE WING & 368130650 & Tug \\
\hline
\end{tabular}

A smaller study area of river spanning 0.15 mile upstream and 0.15 mile downstream of the river mile 282 was selected for a vessel transit speed analysis. The vessel position reports from this area are highlighted in bright blue within Figure 3. This area was selected because it appeared to be distinct from the rock placement and construction activities occurring near river mile 283 . 


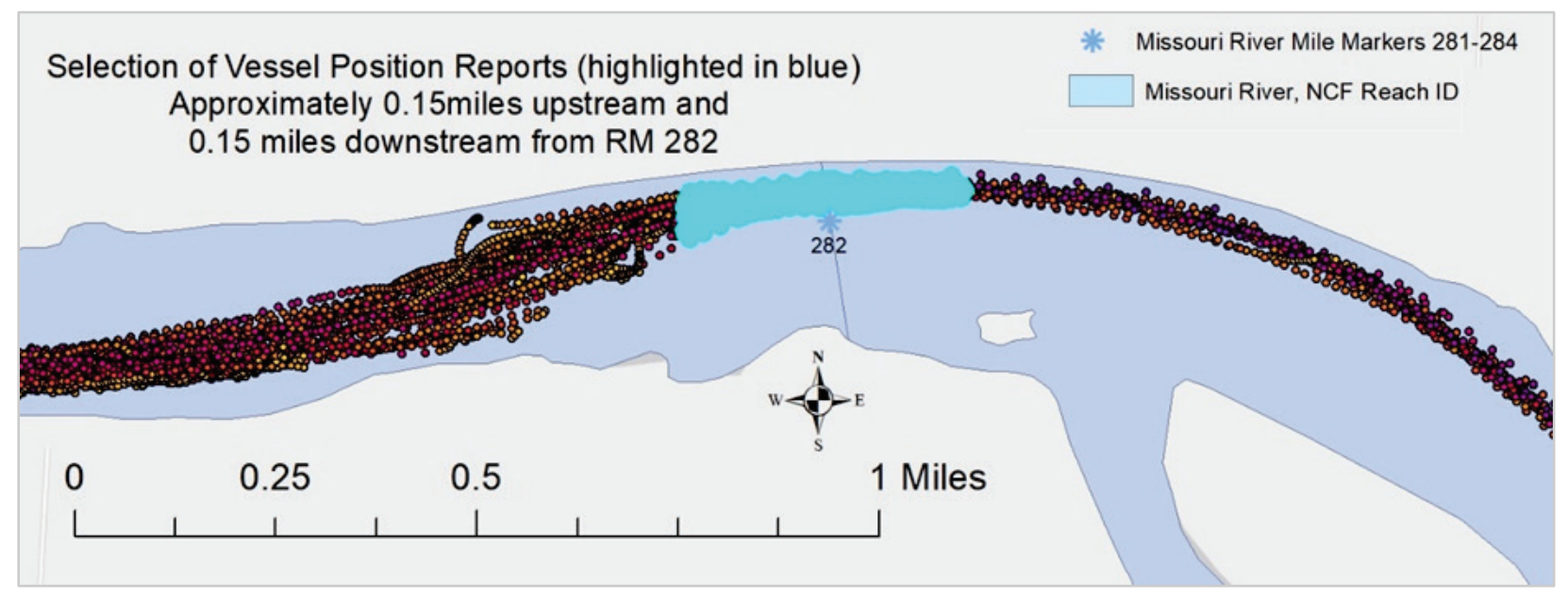

Figure 3. Vessel position reports (bright blue) selected for speed analysis across river mile 282, November 2020. Red and orange dots represent other vessel position reports from November.

All vessel position reports were sorted by vessel MMSI, date, and time. Transits were identified as a continuous set of position reports from a single vessel in an upstream or downstream direction with no gap in position reports longer than 30 seconds. To distinguish between vessels traveling upbound (upstream), and those traveling downbound (downstream), an additional descriptor was generated based on the Course Over Ground (COG) field included in the AIS message. Vessels with COG values from 0 to 179.9 were classified as moving downstream, while those with a COG values of 180 to 360 were classified as moving upstream. Within the limited section of river around river mile 282 (highlighted in blue in Figure 3), the recorded range of COG headings clearly distinguished between downbound vessels (COG 56-98) and upbound vessels (COG 243-303). This allowed for classification of a transit as either upbound or downbound. The set of sequential position reports for a single direction transit were used to calculate the average vessel speed for a single transit; an example of these reports for a single vessel is shown in Table 3.

Table 3. Example of AIS position reports used to calculate average transit speed.

\begin{tabular}{|l|l|l|l|l|l|l|l||}
\hline \multicolumn{1}{|c|}{ Vessel Name in AIS } & \multicolumn{1}{|c|}{ Date } & \multicolumn{1}{|c|}{ Time } & Latitude & Longitude & COG* & SOG** & $\begin{array}{c}\text { Transit } \\
\text { Direction }\end{array}$ \\
\hline CROSBY PROGRESS & $11 / 6 / 2020$ & $12: 28: 40$ & 39.26902 & -93.4208 & 61.4 & 3.8 & Downbound \\
\hline CROSBY PROGRESS & $11 / 6 / 2020$ & $12: 28: 50$ & 39.26913 & -93.4206 & 61.3 & 3.6 & Downbound \\
\hline CROSBY PROGRESS & $11 / 6 / 2020$ & $12: 28: 59$ & 39.2692 & -93.4205 & 61.8 & 3.5 & Downbound \\
\hline CROSBY PROGRESS & $11 / 6 / 2020$ & $12: 29: 18$ & 39.26933 & -93.4201 & 66.9 & 3 & Downbound \\
\hline CROSBY PROGRESS & $11 / 6 / 2020$ & $12: 29: 29$ & 39.26938 & -93.42 & 70.3 & 2.6 & Downbound \\
\hline CROSBY PROGRESS & $11 / 6 / 2020$ & $12: 29: 38$ & 39.26942 & -93.4199 & 67.5 & 2.1 & Downbound \\
\hline CROSBY PROGRESS & $11 / 6 / 2020$ & $12: 29: 50$ & 39.26947 & -93.4197 & 66 & 1.8 & Downbound \\
\hline CROSBY PROGRESS & $11 / 6 / 2020$ & $12: 29: 59$ & 39.26951 & -93.4196 & 62.3 & 1.6 & Downbound \\
\hline CROSBY PROGRESS & $11 / 6 / 2020$ & $12: 30: 08$ & 39.26955 & -93.4195 & 66.1 & 2.1 & Downbound \\
\hline CROSBY PROGRESS & $11 / 6 / 2020$ & $12: 30: 20$ & 39.2696 & -93.4194 & 74.1 & 3.1 & Downbound \\
\hline CROSBY PROGRESS & $11 / 6 / 2020$ & $12: 30: 38$ & 39.26967 & -93.4189 & 80.6 & 4.5 & Downbound \\
\hline
\end{tabular}

${ }^{*} \mathrm{COG}$, Course Over Ground

**SOG, Speed Over Ground.

All dates and times in AIS messages are in Coordinated Universal Time (UTC). 
Individual AIS position reports were converted into a continuous line using the "Points to Line" feature in ArcMap, using the modified Date-Timestamp field to identify sequential reports from the same vessel. Re-created tracklines for all upbound (red) and downbound (blue) transits across river mile 282 in November are shown in Figure 4.

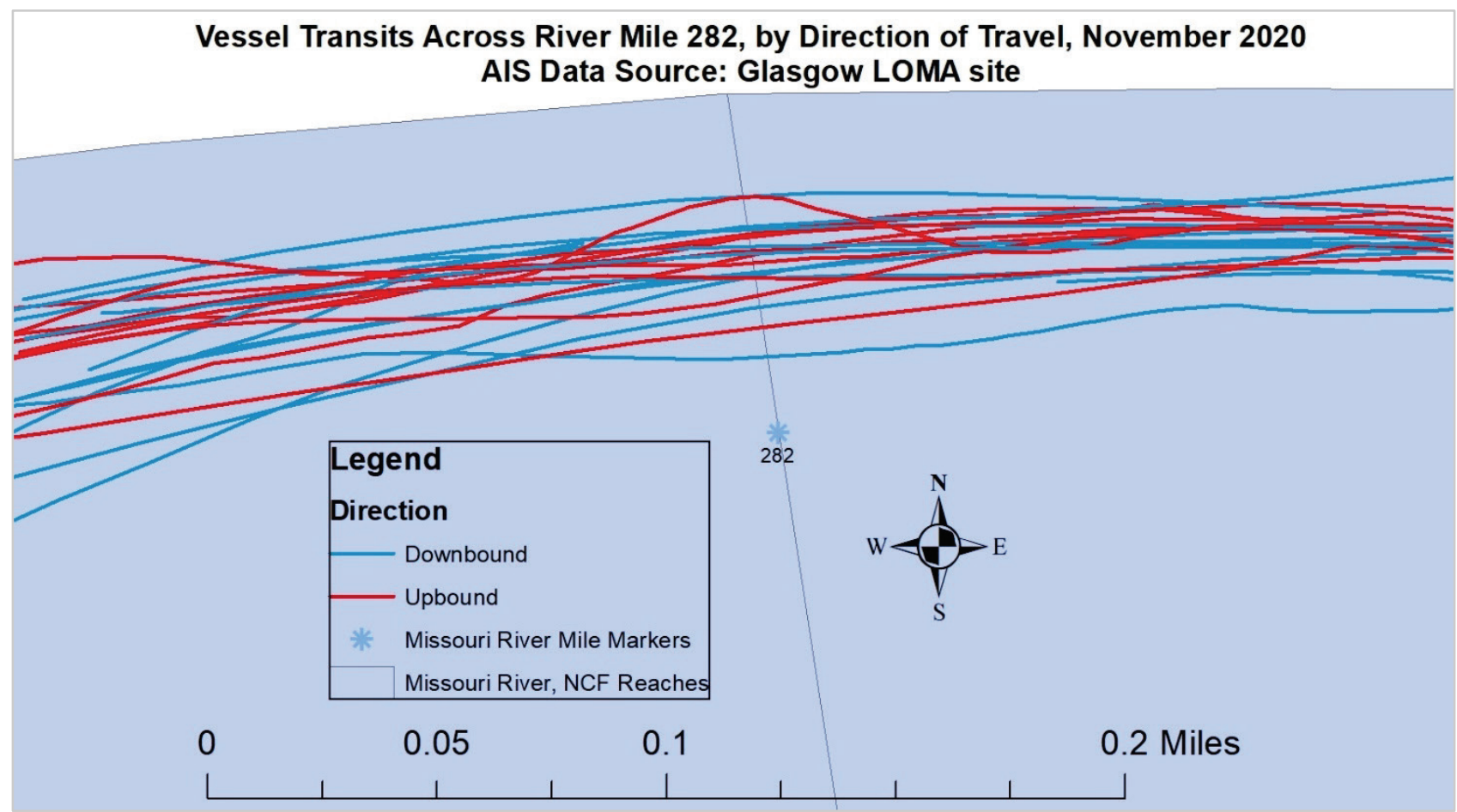

Figure 4. Upbound (red) and Downbound (blue) transits across river mile 282, November 2020.

RESULTS: Based on available AIS records, 23 transits across river mile 282 were identified during the month of November 2020. Of those transits, 13 occurred in the pre-dredging time period (November 1-10), 1 occurred during the time of active dredging (November 11-14), and 9 transits occurred in the post-dredging period (November 15-30). The average vessel speed for each of the 23 vessel transits across the river mile 282 study area during November is shown in Table 4. Vessel tracklines were mapped based on direction of travel and temporal relationship to the dredge event. Figure 5 shows re-created downbound vessel transit tracklines in the pre-dredging time (light pink) and in the post-dredging time (dark pink), all of which were clustered within the river half closest to the left descending bank. Figure 6 shows re-created upbound vessel transit tracklines in the predredging time period (light tan), the during-dredging period (yellow, one transit), and in the postdredging period (brown, one transit). These upbound tracklines were also clustered within the river half closest to the left descending bank. 
ERDC/CHL CHETN-IX-59

February 2022

\begin{tabular}{|c|c|c|c|c|c|c|}
\hline $\begin{array}{c}\text { Transit } \\
\text { Order } \\
\text { across } \\
\text { Mile } 282 \\
\end{array}$ & Vessel ID & Vessel Name & Date & $\begin{array}{l}\text { Downbound } \\
\text { Average } \\
\text { Speed (knots) }\end{array}$ & $\begin{array}{l}\text { Upbound } \\
\text { Average } \\
\text { Speed } \\
\text { (knots) } \\
\end{array}$ & $\begin{array}{l}\text { Dredging } \\
\text { Phase }\end{array}$ \\
\hline 1 & 367474790 & $\begin{array}{l}\text { CROSBY } \\
\text { PROGRESS }\end{array}$ & 6-Nov & 2.88 & & pre-dredging \\
\hline 2 & 367474790 & $\begin{array}{l}\text { CROSBY } \\
\text { PROGRESS }\end{array}$ & 6-Nov & & 3.71 & pre-dredging \\
\hline 3 & 369970375 & STEPHENSON II & 7-Nov & & 4.33 & pre-dredging \\
\hline 4 & 368130650 & WHITE WING & 9-Nov & & 3.46 & pre-dredging \\
\hline 5 & 368130650 & WHITE WING & 9-Nov & 8.60 & & pre-dredging \\
\hline 6 & 368130650 & WHITE WING & 9-Nov & & 1.69 & pre-dredging \\
\hline 7 & 369970845 & JUMBO & 9-Nov & & 2.54 & pre-dredging \\
\hline 8 & 367526190 & ELIZABETH ANNE & 9-Nov & & 4.27 & pre-dredging \\
\hline 9 & 368130650 & WHITE WING & 9-Nov & 9.66 & & pre-dredging \\
\hline 10 & 368130650 & WHITE WING & 9-Nov & & 4.51 & pre-dredging \\
\hline 11 & 369970375 & STEPHENSON II & 10-Nov & 4.12 & & pre-dredging \\
\hline 12 & 369970375 & STEPHENSON II & 10-Nov & & 4.35 & pre-dredging \\
\hline 13 & 367474790 & $\begin{array}{l}\text { CROSBY } \\
\text { PROGRESS }\end{array}$ & 10-Nov & 6.48 & & pre-dredging \\
\hline 14 & 367474790 & $\begin{array}{l}\text { CROSBY } \\
\text { PROGRESS }\end{array}$ & 13-Nov & & 3.30 & $\begin{array}{l}\text { during- } \\
\text { dredging }\end{array}$ \\
\hline 15 & 369970375 & STEPHENSON II & 15-Nov & 8.53 & & post-dredging \\
\hline 16 & 367474790 & $\begin{array}{l}\text { CROSBY } \\
\text { PROGRESS }\end{array}$ & 16-Nov & 6.69 & & post-dredging \\
\hline 17 & 367474790 & $\begin{array}{l}\text { CROSBY } \\
\text { PROGRESS }\end{array}$ & 16-Nov & & 3.17 & post-dredging \\
\hline 18 & 367718940 & LESLIE ANN & 17-Nov & 7.32 & & post-dredging \\
\hline 19 & 368130650 & WHITE WING & 23-Nov & 2.74 & & post-dredging \\
\hline 20 & 368131420 & FAR WEST & 25-Nov & 4.01 & & post-dredging \\
\hline 21 & 367057220 & CAPT TONY ICE & 27-Nov & 7.76 & & post-dredging \\
\hline 22 & 369970845 & JUMBO & 30-Nov & 8.88 & & post-dredging \\
\hline 23 & 367663940 & DAISY BELL & 30-Nov & 8.38 & & post-dredging \\
\hline
\end{tabular}




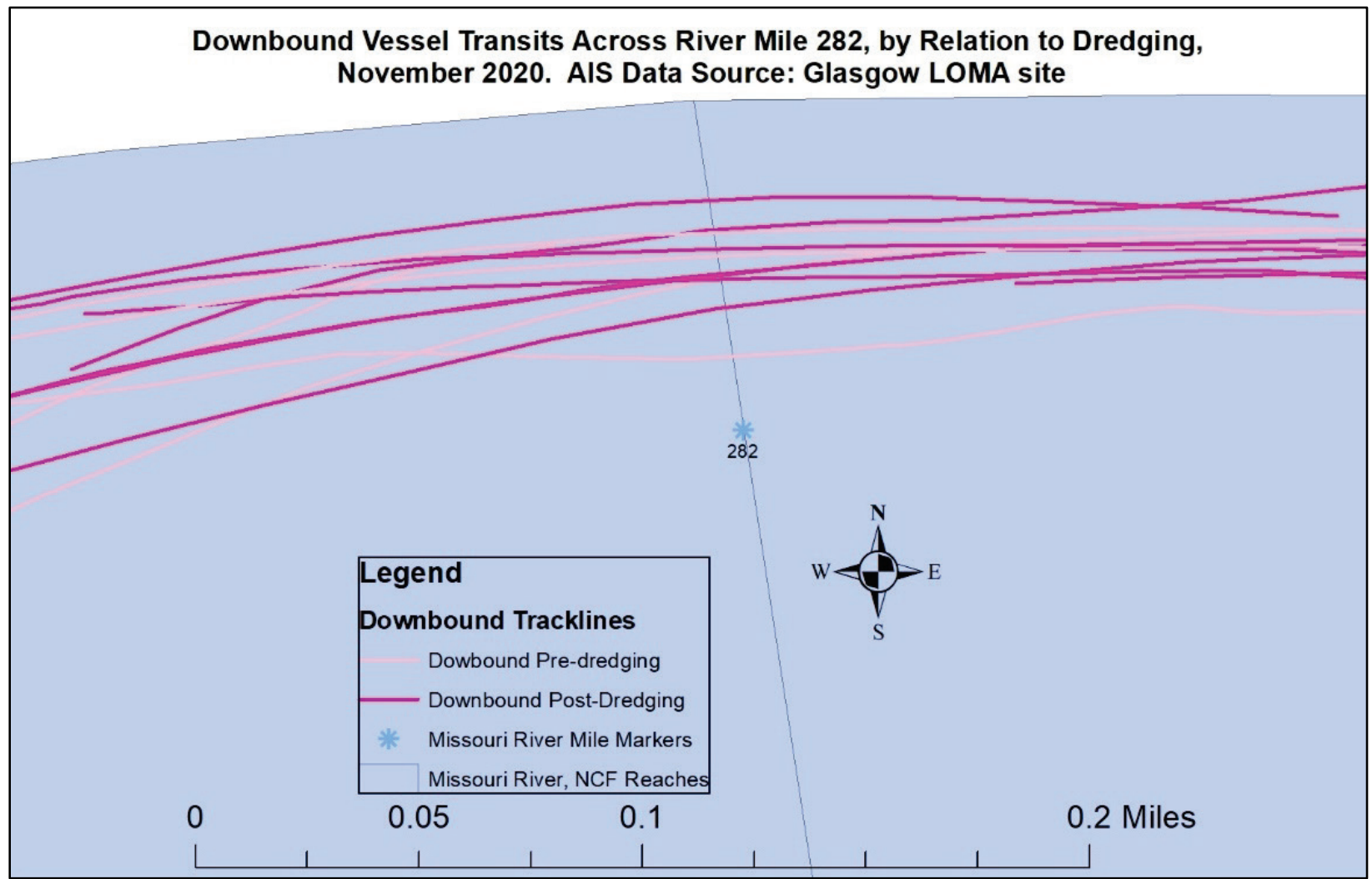

Figure 5. Downbound vessel transits across river mile 282, pre- and post-dredging.

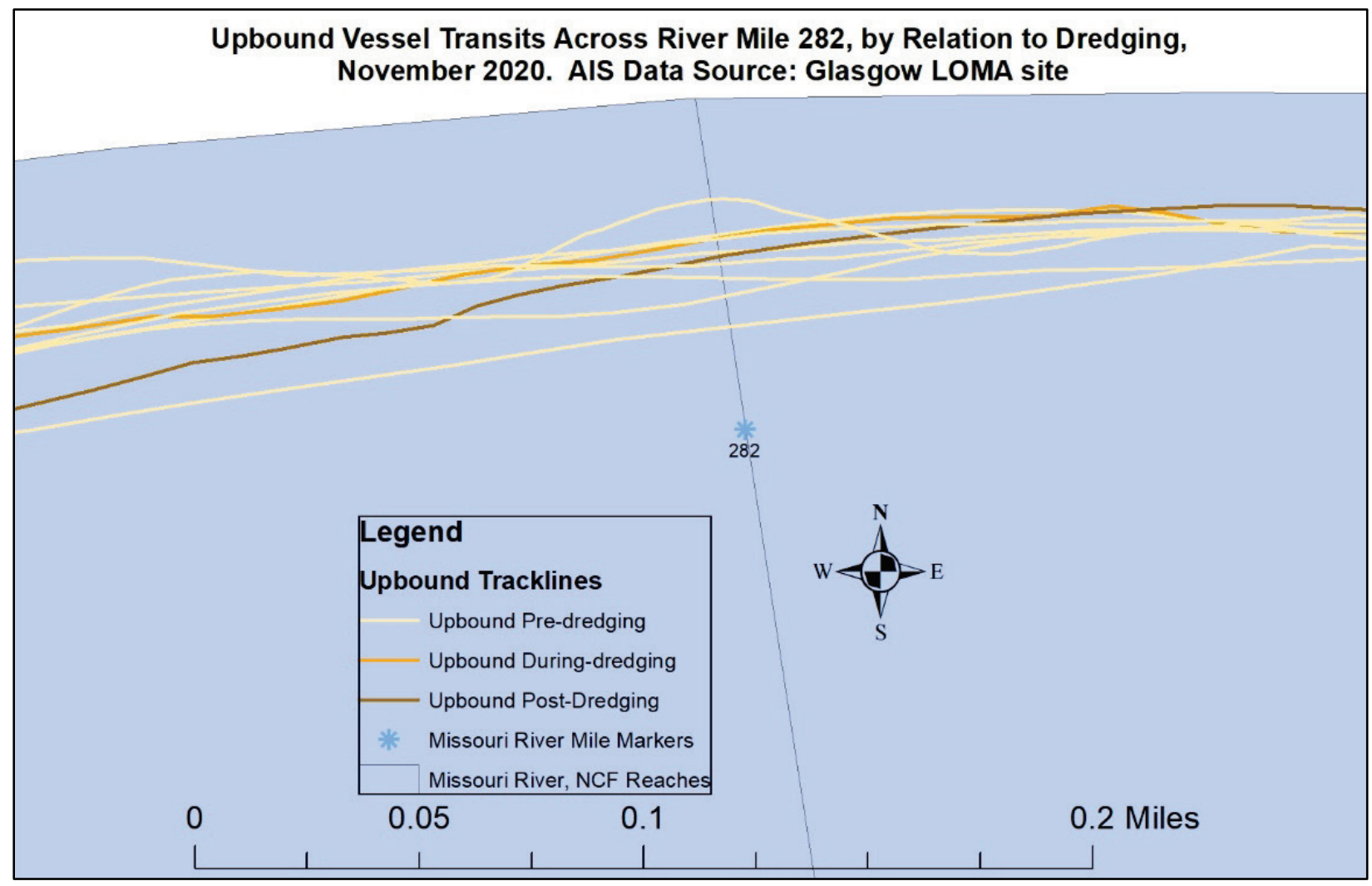

Figure 6. Upbound vessel transits across river mile 282, pre-, during-, and post-dredging. 
Table 5 displays the average transit speed for vessels that crossed river mile 282 in the pre-dredging and post-dredging time periods, separated by upbound and downbound direction of travel. There was a slight increase in average downbound transit speed across river mile 282 in the eight transits that were observed in the post-dredging time period, but this was not statistically significant. There was only one upbound transit observed in the post-dredging time period, so no meaningful conclusions about the difference in upbound vessel speeds pre- or post-dredging can be made from this sample of vessel transits.

Table 5. Average transit speed across river mile 282, pre- and post-dredging, November 2020.

\begin{tabular}{||l|c|c||}
\hline $\begin{array}{c}\text { Transit across river mile 282, } \\
\text { November 2020 }\end{array}$ & $\begin{array}{c}\text { Average speed } \\
\text { (knots) }\end{array}$ & $\begin{array}{c}\text { Number of transits included } \\
\text { in speed calculation }\end{array}$ \\
\hline Average upbound speed pre-dredging & 3.61 & 8 \\
\hline Average upbound speed post-dredging & 3.17 & 1 \\
\hline Average downbound speed pre-dredging & 6.35 & 5 \\
\hline Average downbound speed post-dredging & 6.79 & 8 \\
\hline
\end{tabular}

Taken together, these results suggest that any true impacts of dredging on vessel speed at this location would be better observed during the next navigation season starting in spring 2021, possibly in comparison to additional data from pre-dredging months in 2020 or 2019, if AIS records are available. Additional analysis of local vessel speeds would benefit from data on important variables such as water level, number of barges in a tow transit, and weather conditions, none of which were examined as part of this report.

The examination of vessel traffic before, during, and after a dredging event is just one application of AIS data. The reader may be interested in publications describing how archived AIS records have been used to research waterway utilization (Kress et al. 2020; Mitchell and Scully 2014; Young and Scully 2018), maritime resilience topics (Scully and Chambers 2019; Touzinsky et al. 2018), developing designs for maritime structures such as storm surge barrier gates (Kress and Weintraub 2021), and examining vessel interactions with structures such as navigation locks under different river flow conditions (Tabbert et al. 2020).

ADDITIONAL INFORMATION: This CHETN was prepared by Marin Kress, Marin.M.Kress@usace.army.mil, US Army Engineer Research and Development Center, Coastal and Hydraulics Laboratory. The ORCiD number for Marin M. Kress is 0000-0002-5835-5686. Appreciation is expressed to Brian Tetreault and the LOMA team for AIS data, to USACE Kansas City staff for providing local knowledge of the Missouri River, and to Charles (Eddie) Wiggins for technical direction. This work is dedicated to the memory of Timothy Welp, dredging expert and mentor.

This CHETN is funded by the USACE Navigation Systems Research Program and should be cited as follows:

Kress, M. M. 2022. Vessel Speed Analysis before and after Dredging around Missouri River Mile 282 in November 2020. ERDC/CHL CHETN-IX-59. Vicksburg, MS: US Army Engineer Research and Development Center. http://dx.doi.org/10.21079/11681/43283 


\section{REFERENCES}

ESRI. 2019. ArcMap 10.7.1. [software program]. Redlands, CA. https://support.esri.com/en/products/desktop/arcgisdesktop/arcmap/10-7-1

Kress, M. M., B. J. Tetreault, K. N. Mitchell, M. Balazik, and M. C. Booton. 2020. AIS Data: Real-Time Operation Support, Incident Investigations, and Waterway Use Analysis. ERDC/CHL CHETN-IX-53. Vicksburg, MS: US Army Engineer Research and Development Center. http://dx.doi.org/10.21079/11681/36395

Kress, M. M., and S. Weintraub. 2021. AIS Data Case Study: Selecting Design Vessels for New Jersey Back Bays Storm Surge Barriers Study. ERDC/CHL CHETN-IX- 54. Vicksburg, MS: US Army Engineer Research and Development Center. http://dx.doi.org/10.21079/11681/39779

Lowe, J. 2020. "US Army Engineer Research and Development Center Assists Kansas City Corps with Hydrodynamic Dredge." Defense Visual Information Distribution Service Website. Story ID 385609. Kansas City, MO. https://www.dvidshub.net/news/385609/us-army-engineer-research-and-development-center-assists-kansas-city-corpswith-hydrodynamic-dredge

Mitchell, K. N., and B. N. Scully. 2014. "Waterway Performance Monitoring via Automatic Identification System (AIS) Data." Transportation Research Record: Journal of Transportation 2426(1): 20-26. https://doi.org/10.3141/2426-03

Murray, D. 2020. "Missouri River Still Facing Shoaling, Uncertain Levels." The Waterways Journal Weekly. The Waterways Journal, Inc.: St. Louis, MO. https://www.waterwaysjournal.net/2020/12/15/missouri-river-still-facingshoaling-uncertain-levels/

Scully, B. M., and K. F. Chambers. 2019. "Measuring Port Disruptions with Automatic Identification System Data." Ports 2019: Port Planning and Development. Reston, VA: American Society of Civil Engineers.

Tabbert, C., J. Vest, A. Rhoads, D. Myers, T. Lauth, E. Brauer, J. Wallace, D. Gordon, and M. Kress. 2020. AIS Data Case Study: River Level and Vessel Approach Variation at Melvin Price Locks and Dam in St. Louis District. ERDC/CHL CHETN-IX-51. Vicksburg, MS: US Army Engineer Research and Development Center. http://dx.doi.org/10.21079/11681/35957

Touzinsky, K. F., B. M. Scully, K. N. Mitchell, and M. M. Kress. 2018. “Using Empirical Data to Quantify Port Resilience: Hurricane Matthew and the Southeastern Seaboard." Journal of Waterway, Port, Coastal, and Ocean Engineering 144(4): 05018003. https://ascelibrary.org/doi/10.1061/\%28ASCE\%29WW.1943-5460.0000446

USACE (US Army Corps of Engineers). 1996. Engineering and Design: Navigation and Dredging Operations and Maintenance Guidance and Procedures. EP 1130-2-520. Washington, DC: Department of the Army, USACE. https://www.publications.usace.army.mil/Portals/76/Publications/EngineerPamphlets/EP 1130-2-520.pdf

USACE-NWK (US Army Corps of Engineers-Kansas City District). 2020. "Missouri River Channel Restriction, September 28, 2020." Notice To Navigation Interests; Notice 12588; Local Number NWK-2020-001; Waterway Missouri River. Kansas City, MO.

https://ntninotices.usace.army.mil/lpwb/download.file? in control nbr=12588\&in file id $=1$

USACE-WCSC (US Army Corps of Engineers-Waterborne Commerce Statistics Center). 2021. 2019 - Missouri River, Kansas City to the Mouth (WATERWAY). Ports and Waterways Webtool. http://cwbi-ndc-nav.s3-website-us-east1.amazonaws.com/files/wcsc/webpub/\#/report-landing/year/2018/region/2/location/6474

Young. D., and B. Scully. 2018. “Assessing Structure Sheltering via Statistical Analysis of AIS Data.” J. Waterway, Port, Coastal, and Ocean Engineering 144(3): 04018002. https://doi.org/10.1061/(ASCE)WW.1943-5460.0000445

NOTE: The contents of this technical note are not to be used for advertising, publication or promotional purposes. Citation of trade names does not constitute an official endorsement. 